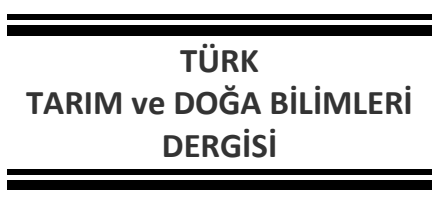



www.dergipark.gov.tr/turkjans

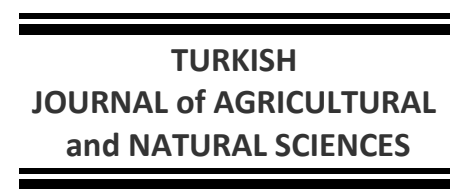

\title{
Araştırma Makalesi \\ Coğrafi Bilgi Sistemleri ve Uzaktan Algılama Yöntemleri ile Arazi Örtüsü/Alan Kullanım Değişimlerinin Belirlenmesi: Bingöl Kent Merkezi Örneği ${ }^{*}$
}

\author{
Sülem ŞENYiĞiT DOĞAN ${ }^{1 *}$, Sevgi YILMAZ² \\ ${ }^{1}$ Peyzaj Mimarlığı Bölümü, Ziraat Fakültesi, Bingöl Üniversitesi \\ ${ }^{2}$ Peyzaj Mimarlığı Bölümü, Mimarlık ve Tasarım Fakültesi, Atatürk Üniversitesi \\ *Sorumlu yazar: sulemsenyigit@hotmail.com
}

Geliş Tarihi: 18.04.2019

Düzeltme Geliş Tarihi: 04.07.2019

Kabul Tarihi: 04.07.2019

Özet

Geçmişi çok eski tarihlere dayanan kentleşme, sanayi devrimi ve gelişen teknolojik faaliyetlerle birlikte çok hızlı bir değişim sergilemiştir. En kalıcı değişim ise yanlış alan kullanımdan kaynaklı olarak arazi örtüsü üzerinde gerçekleşmektedir. Bu nedenle kentlerin sağlıklı bir şekilde büyüyebilmesi için sahip oldukları arazi örtüsünün sürdürülebilir kullanımını sağlayacak şekilde yönetilmesi ve planlanması gerekmektedir. Günümüzde zamanla gerçekleşen bu hızlı ve dinamik değişimi analiz edebilmek için Coğrafi Bilgi Sistemleri ve Uzaktan Algılama yöntemleri etkin bir şekilde kullanılmaktadır. Bu amaçla çalışmada 1985-2017 yılları arasındaki yaklaşık 32 yıllık süre içerisinde Bingöl kent merkezinde arazi örtüsü/alan kullanımında meydana gelen değişim uydu görüntüleri kullanılarak incelenmiştir. 1985 ve 2000 yıllarına ait 30m konumsal çözünürlüğe sahip Landsat 4-5 TM ve 2017 yılına ait 10m konumsal çözünürlüğü olan Sentinel-2 uydu görüntüleri ile birlikte Arcgis 10.4.1 ve Erdas İmagine 2014 yazılımları kullanılarak değişim süreci değerlendirilmiştir. Uydu görüntülerine kontrollü sınıflandırma yöntemi uygulanmış ve yöntem için kentsel alan, tarım alanı, yeşil alan, su kütleleri ve boş alan olmak üzere 5 ana sınıf belirlenmiştir. Sınıflandırma sonucu elde edilen görüntülere doğruluk analizi uygulanmış ve 1985 yılına ait sınıflandırılmış görüntü için \%95, 2000 yılına ait sınıflandırılmış görüntü için \%96, 2017 yılına ait sınıflandırılmış görüntü için ise \%92 doğruluk sonuçları elde edilmiştir. Bulgular sonucunda 1985 yılından 2017 yılına kadar Bingöl kent merkezinde kentsel alanlarda 512 ha miktarında bir artış olduğu gözlemlenmiştir. Su varlığında 54 ha ve boş alanlarda 712 ha azalma, yeşil alan miktarında 231 ha ve tarım alanlarında 13 ha artış yaşandığı sonucuna ulaşılmıştır. Arazi örtüsü üzerinde hangi alan kullanımlarının geliştiği belirlenmiş ve gelişim yönleri tespit edilmiştir. Elde edilen sonuçlar doğrultusunda gelecekteki büyümesi beklenen kent merkezi ile ilgili sürdürülebilir alan kullanımına yönelik önerilerde bulunulmuştur.

Anahtar kelimeler: Arazi örtüsü/alan kullanım değişimi, Bingöl, coğrafi bilgi sistemleri, uzaktan algılama yöntemleri, uydu görüntüleri.

\section{Determination of Land Cover/ Land Use Changes with Geographıc Information Systems and Remote Sensing Methods: Bingol City Center Example}

\footnotetext{
Abstract

The urbanization, with its roots in ancient times, has rapidly changed with the industrial revolution and development of technological achievements. The most persistent change which happens to vegetation is due to improper land use. For a good urban growth, cities must be managed and planned to ensure the sustainable use of the vegetation. Today, Geographical Information Systems and Remote Sensing are effective methods for fast and dynamic analysis of changes, to this aim, the change in land cover / land use in city center of Bingöl was investigated
} 
in timespan of 32 years between 1985-2017 using satellite images. The softwares used for the evaluation of the images for the years between 1985-2000 was Landsat 4-5 TM with a positional resolution of 30m, and Sentinel-2 satellite images with a spatial resolution of 10m using the ArcGIS 10.4.1 and Erdas Imagine 2014 software for 2017. Controlled classification method was applied to satellite images and and 5 main classes were determined for this method: urban area, agricultural area, green area, water bodies and free space. Accuracy assesment was applied to the images obtained as a result of the classification and it was $95 \%$ for the classified image of $1985,96 \%$ for the classified image for the year 2000 and $92 \%$ for the classified image of the year 2017. As a result of the findings, an increase of 512 ha was observed in the residential areas of Bingöl city from 1985 to 2107 . In the presence of water, it was concluded that there were 54 ha and 712 ha decrease in free spaces, 231 ha in green area and 13 ha increase in agricultural areas. It was determined which land uses on land cover were developed and what the development ways were. Based on the results obtained, suggestions for sustainable land use were made about the city center which is expected to be expanded in the future.

Key words: Land cover / land use change, Bingöl, geographical information systems, remote sensing methods, satellite imagery.

\section{Giriş}

Arazi örtüsü (AÖ) dünya yüzeyinin tüm özelliklerini bulunduran alan olarak tanımlanmaktadır (Ramachandra ve Bharath, 2012). İnsan yaşamının var olmasından bu yana gerçekleştirdiği tüm faaliyetler arazi örtüsünün sunmuş olduğu kaynaklara bağııdır. Arazi örtüsünün yetenek sınıflarına uygun kullanılmaması neticesinde, topraklar doğal özelliklerin yitirmektedirler. Orman, tarım veya mera alanlarının yerine yerleşim ve sanayi alanlarının büyümesi, toprakların verimsizleşmesine, katı atıklarla kirlenmesine neden olmaktadır (Öztürk ve ark., 2010; Gülersoy, 2014). Kentler, dünya yüzeyinin oransal olarak çok az miktarının kaplamış olmalarına rağmen arazi örtüsü üzerindeki değişimin yoğun olarak görüldüğü yerlerdir (Oğuz ve ark., 2012).

$1800^{\prime} l u ̈$ yılların başında dünya üzerinde bulunan tüm kentlerde yaklaşık 50 milyon insan yaşamını sürdürmekteyken bu rakam 2 milyar sayıya ulaşarak önemli ölçüde artış göstermiştir. Fakat bu artışla birlikte dünya nüfusu giderek kentsel alanlarda yoğunlaşmaya başlamıştır. Türkiye'nin artan nüfusu 1950 yılları sonrasında kentlerde toplanmaya başlamış kentleşme oranı o yıllarda \%29,0 iken, 2000 yılında \%47,1 oranına kadar yükselmiştir (Çelebi, 2018). Kentlerde yaşanan aşırı nüfus artışına bağı hatalı yapılaşma ve yanlış arazi kullanımları, doğal kaynakların sürdürülebilir olmayacak şekilde kullanımı gibi kentler için birçok çevre sorunlarına sebep olmakta ve bu durum gelecekteki kent yaşamını tehdit etmektedir. Bu hıza uyum sağlamak için de yeni teknolojilere gereksinim duyulmaktadır. Uzaktan Algılama teknikleri ve Coğrafi Bilgi Sistemleri bu gereksinimin karşılanmasında önemli bir rol oynamaktadır (Calda, 2010).
Kentlerin de insan hayatına benzer şekilde büyüme ve gelişme evreleri vardır (Şahap, 2015). Kentsel planlama çalışmaları ile bu evrelerin entegrasyonunu sağlamak sağlıklı büyüyen kentler için büyük önem arz etmektedir. Bingöl kenti sahip olduğu doğal su kaynakları ve doğal peyzaj özellikleri ile ülkemiz için önemli değere sahiptir (Vural, 2019). Fakat son dönemlerde kent merkezi alanında yerleşim alanlarının hızlı artışı alan kullanımı (AK) değişimlerinin ne yönde değiştiği sorusunu düşündürmektedir. TÜiK verilerine göre Bingöl için 1965 yılında kentleşme oranı nüfus bazında \%13,6, 2000 yilında \%48,7 ve 2017 yilında ise $\% 64,3$ olarak belirtilmiştir (TÜiK 2017). Kentleşmeye yön veren bir diğer olgu kentin sahip olduğu sosyoekonomik yapıdır. Bir kentin sosyoekonomik yapısını üretim ve gelir düzeyi, demografik yapı, eğitim ve sağlık alanındaki olanaklar, işgücü isteği, fiziki ve sosyal alanlarda altyapı imkanları gibi faktörler etkilemektedir (Erdoğan ve ark., 2018).

Bingöl kenti bulunduğu bölge olan Doğu Anadolu Bölgesi ve aynı zamanda Türkiye ortalamalarına göre sosyoekonomik gelişmişlik düzeyi daha düşük seviyelerde bulunmaktadır (Erkan ve ark., 2012). Bunun nedenleri arasında en büyük etken kentin ekonomisinin tarım ve hayvancılığa dayalı olması ve bu faaliyetlerin geleneksel yöntemler ile yapılmasından kaynaklanmaktadır. Geçmişten bugüne sürekli artı̧̧ gösteren kentleşme oranı gelecekte de bu değişimi göstermesi arazi örtüsü üzerindeki baskının artmasına neden olabileceğini göstermektedir. Bu doğrultuda geçmişten günümüze kentsel gelişim dönemleri doğru bir şekilde analiz edilirse, ileri dönemdeki alansal gelişim için sürdürülebilir kullanım doğrultusunda daha planlı kararlar alınabilmektedir. Bu çalışmanın temel amacı Bingöl kent merkezinin 
1985-2017 yılları arasındaki arazi örtüsü/alan kullanımdaki değişimini belirli periyotlarla tespit etmek, gelecek çalışmalara ışık tutması için elde edilen sonuçların kent merkezine olumlu veya olumsuz etkilerini analiz etmek ve geleceğe yönelik kentsel gelişimin ne yönde ilerlemesi gerektiği ile ilgili öneriler sunmaktır.

\section{Materyal ve Yöntem}

Çalışma alanı olarak seçilen Bingöl kent merkezi, Doğu Anadolu Bölgesinin Yukarı Fırat Bölümünde, Çapakçur ve Gayt Derelerinin Bingöl Ovasına birleştiği arazide bulunmaktadır. Kent merkezi sınırlarını belirlemek için Bingöl Belediyesinden temin edilen 1:1000 ölçekli uygulama imar planından faydalanılmış ve bu doğrultuda belirlenen çalışma bölgesi yaklaşık olarak 3653 ha'lık bir alana sahiptir (Şekil 1.).

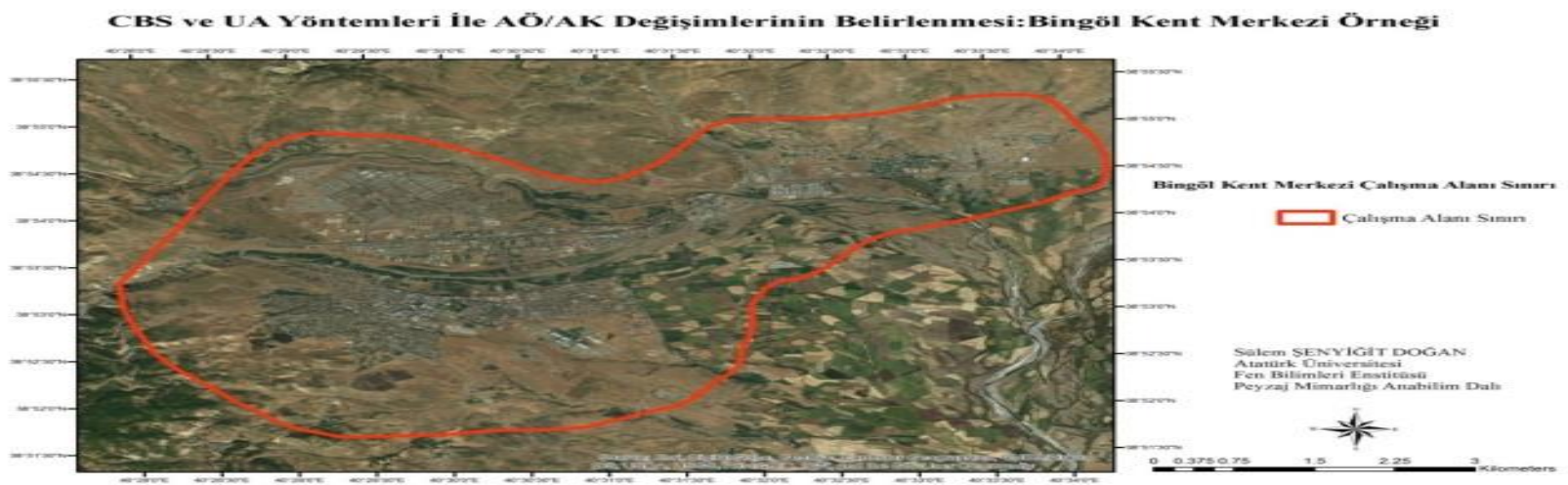

Şekil 1. Bingöl kent merkezi mücavir alan sınırına göre belirtilmiş çalışma alanı sınırı.
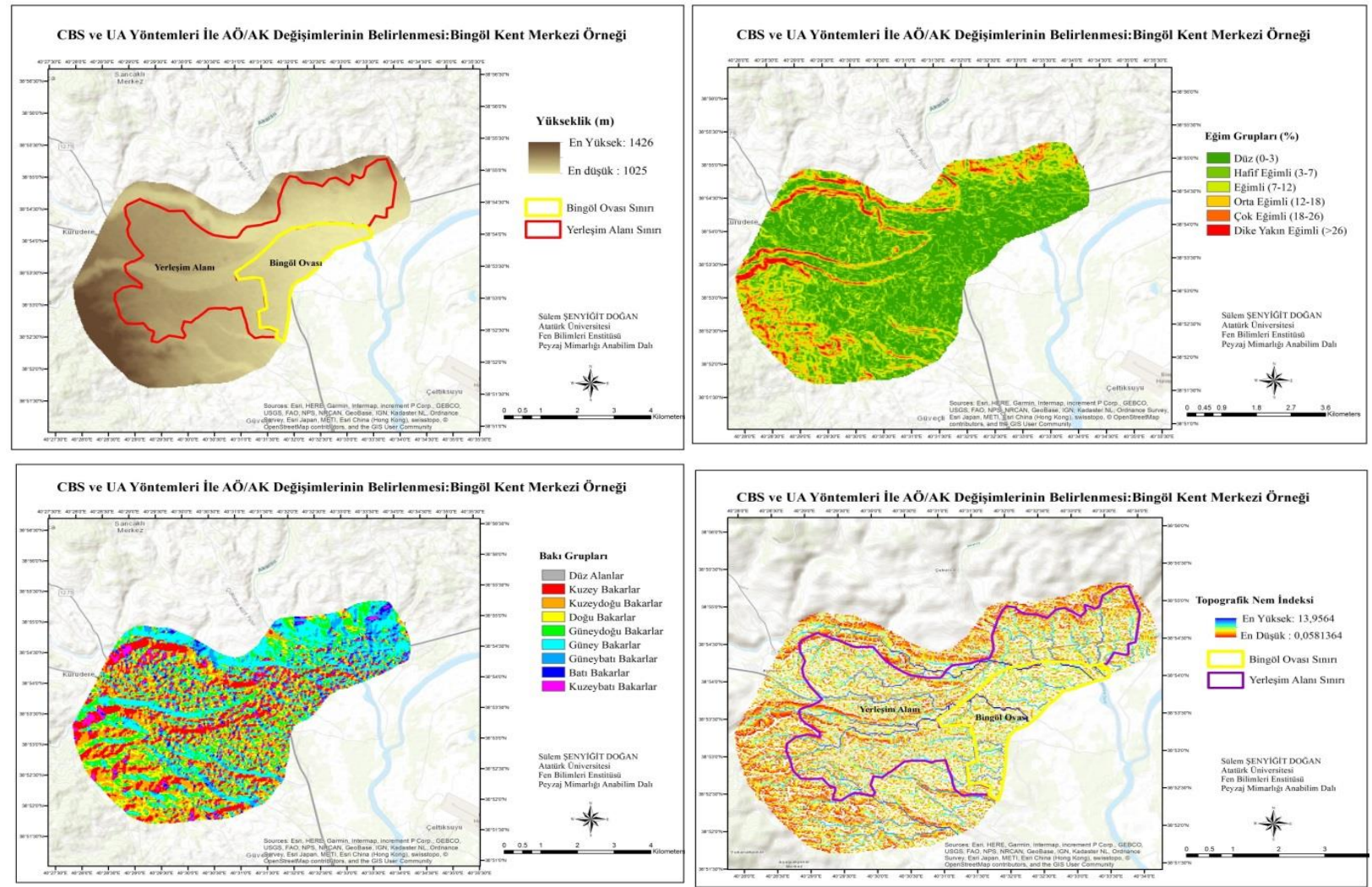

Şekil 2. Bingöl kent merkezi yükseklik, eğim, bakı ve topografik nem indeksi haritaları.

Bingöl kent merkezi düz bir yapıya sahip ve

yükseltisi 1025-1426 metre arasında değişmektedir. 
Kent merkezinden kuzeye ve batıya gidildikçe yükseltiler artış göstermekte, aynı zamanda bu bölgelerde eğimli alanlar da yoğunlaşmaktadır. Çalışma alanı sınırı içinde kalan bölge bakı grupları açısından da çeşitlilik göstermektedir. Araştırma alanına ait yükseklik, eğim, topografik nem indeksi ve bakı haritaları USGS explorer web sitesinden ücretsiz olarak indirilen DEM verisi kullanılarak elde edilmiştir (Şekil 2).

Yaklaşık 500 km2'lik bir yüzeye sahip Bingöl ovası Türkiye'nin en aktif jeolojik unsurlarından biri olan Doğu Anadolu fayı üzerinde bulunmaktadır
(Tonbul, 1990). Araştırma alanı olan Bingöl kent merkezi de ovanın kuzeyinde konumlanmış olması ve aynı zamanda ülkemizde bulunan ve dünyadaki en tehlikeli fay hattı olarak bilinen Kuzey Anadolu Fayı'nın da etkisinde de olmasından dolayı deprem tehlikesi yönünden 1 . derece riskli bölge olarak bilinmektedir (Seymen ve ark., 1972).

Tüik verilerine göre nüfus gelişimi incelendiğinde ise 1965-2017 yıllarını kapsayan 52 yıllık süreçte kent merkezi nüfusu $11,727^{\prime}$ den 117,014 'e yükselerek yaklaşık 10 kat kadar bir artış göstermiştir (Şekil

3).

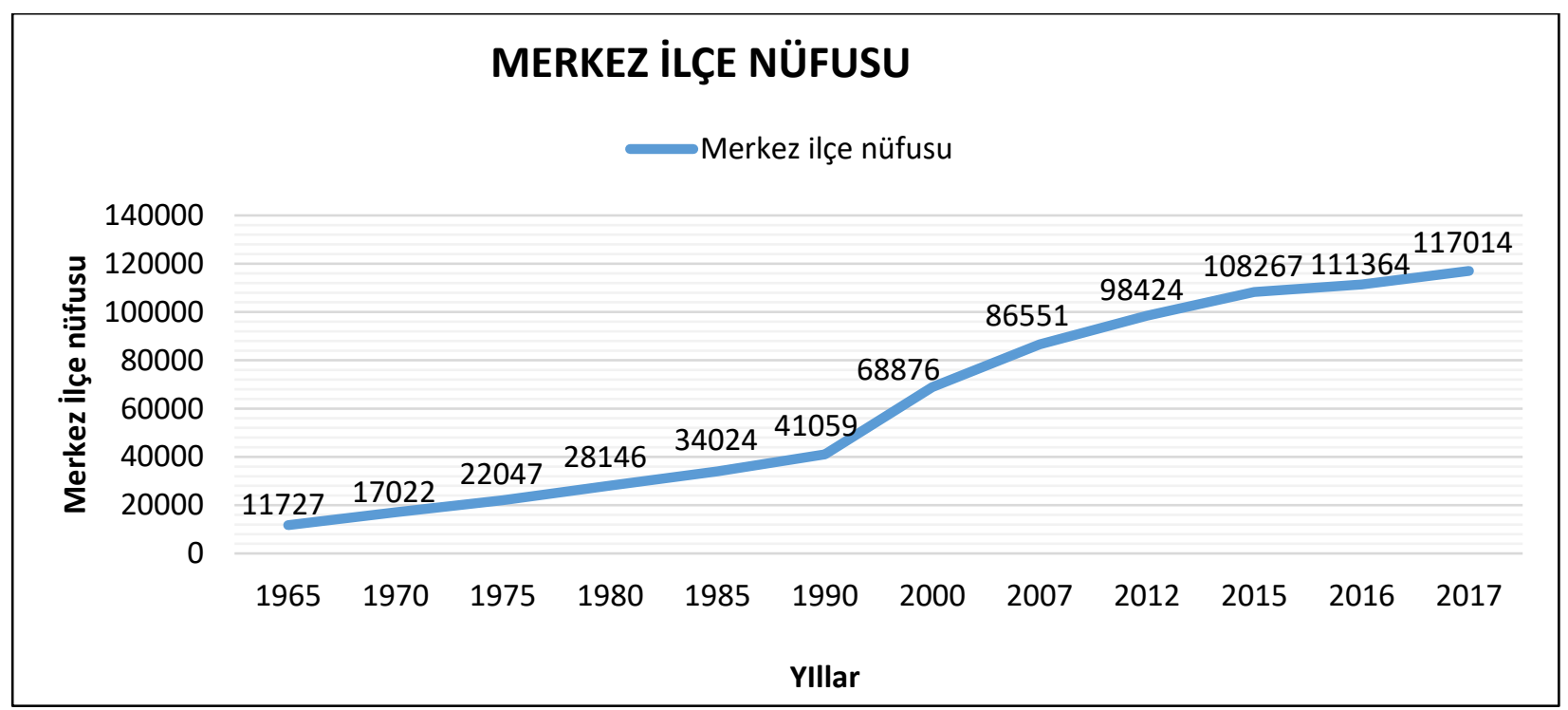

Şekil 3. Bingöl merkez ilçe 1965-2017 yılları arası nüfus değişimi (TÜiK, 2017).

Araştırmada uygulanacak aşamalar Oğuz ve ark., 2012, Gezici, 2012, Doygun ve ark., 2015, Rawat ve ark., 2015'in kentsel alanlarda AÖ/AK değişim analizi ile ilgili çalışmalarındaki yaklaşımlar temel alınarak hazırlanmıştır. Ayrıca uygulanacak yöntemin belirlenmesi aşamasında Çukurova Üniversitesi Peyzaj Mimarlığı Bölümü Uzaktan Algılama ve Coğrafi Bilgi Sistemleri Laboratuarında hizmet veren Öğretim Üyelerinden destek alınmıştır. Bingöl kent merkezinin AÖ/AK değişimini analiz etmek amacıyla farklı üç tarihe ait uydu görüntüleri kullanılmıştır. Bunlar 30m yer çözünürlüğüne sahip 9 Haziran1985 ve 2 Temmuz 2000 tarihli ait Landsat 4-5 TM uydu görüntüleri ve 21 Ağustos 2017 tarihli 10m yer çözünürlüğü olan Sentinel-2 uydu görüntüsüdür. Kullanılan uydu görüntüleri USGS Glovis web sitesinden ücretsiz olarak indirilerek temin edilmiştir (Anonim, 2018). Uydu görüntülerinin sınıflandırılmasında ve sınıflandırma sonrası verileri depolama işlemlerinde ArcGIS 10.4.1 ve ERDAS Imagine 2014 yazılımları kullanılmıştır. Geçmiş çalışmalardan edinilen bilgiler ışığında hata oranını en aza indirmek amacıyla sınıflama yöntemlerinden kontrollü sınıflama yöntemi tercih edilmiş ve sınıflandırma ERDAS Imagine 2014 yazılımı yardımıyla uygulanmıştır. Alan kullanımlarının sınıflandırılmasında, Bingöl kentsel yapısını ve özelliklerini ayırt etmeye yardımcı olacak şekilde 5 farklı alan kullanım sınıfı belirlenmiştir (Çizelge 1).

Alan sınıfları belirlendikten sonra kontrollü sınıflandırmanın ilk aşaması olan eğitim kısmı, arazi analizi çalışması, fotoğraf alma ve uydu görüntüleri gibi diğer kaynaklardan yararlanmak kaydıyla, arazi üzerinde hangi sınıfı temsil ettiğini yaklaşık olarak bildiği piksellerden eşit dağılımla örnekler alarak uygulandığı aşama gerçekleştirilmiştir. Bu aşamadan sonra alınan örneklerin referansıyla görüntünün kontrollü sınıflandırması (supervised classification), maksimum olasılık (maximum likehood) algoritması kullanılarak tamamlanmıştır. Kontrollü sınıflandırma 
işlemi uygulanmış tematik haritaların doğruluk analizleri yapıldıktan sonra her üç yıla ait arazi örtüsü/alan kullanımları elde edilmiştir. Bulgular sonucunda dönemler bazında Bingöl kent merkezi arazi örtüsü/alan kullanım değişimleri analiz edilmiş ve kent merkezinin sürdürülebilir planlamasına yönelik çeşitli önerilerde bulunulmuştur.

Çizelge 1.Çalışmada kullanılan alan kullanım sınıfları

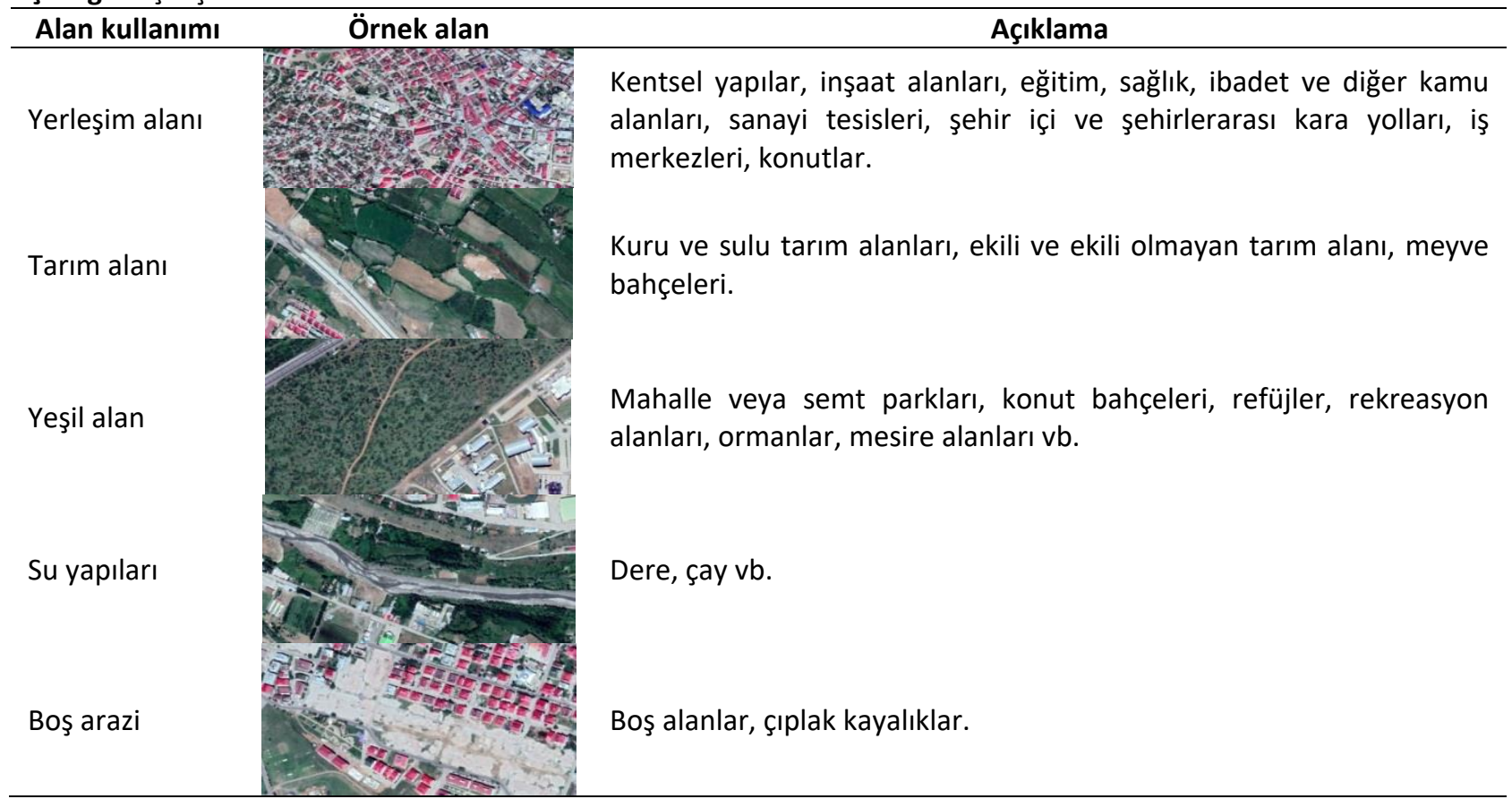

Bulgular ve Tartışma

1985-2000-2017 yıllarına ait kontrollü sınıflandırılmış görüntülerin doğruluk analizleri

Kontrollü sınıflandırılmış görüntü üzerine her sınıf için 20 örneklem ile uygulanan analiz sonuçları çizelgelerle belirtilmiştir. Buna göre 1985 yılına ait hata matrisi ve doğruluk analizi Çizelge 1'de, 2000 yılına ait hata matrisi ve doğruluk analizi Çizelge 2'de, 2017 yılına ait hata matrisi ve doğruluk analizi Çizelge 3'de verilmiştir.
Bu doğrultuda gerçekleştirilen doğruluk analizleri sonucunda en yüksek genel sınıflandırma doğruluk değeri \%96 ile Çizelge 3.'de belirtilen 2000 tarihli kontrollü sınıflandırma uygulanmış Landsat 4-5 TM görüntüsünde gözlemlenmiştir. En düşük doğruluk değeri ise \%92 ile Çizelge 4.'de belirtilen 2017 tarihli kontrollü sınıflandırma uygulanmış Sentinel-2 görüntüsünde görülmektedir.

Çizelge 2. 1985 yılı kontrollü sınıflandırma hata matrisi ve doğruluk analizi

\begin{tabular}{|c|c|c|c|c|c|c|c|}
\hline Sınıf adı & $\begin{array}{c}\text { Yerleşim } \\
\text { alanı }\end{array}$ & Su kütleleri & $\begin{array}{l}\text { Tarım } \\
\text { alanı }\end{array}$ & Yeşil alan & Boş alan & Satır toplamı & Kullanıcı doğruluğu \\
\hline Yerleşim alanı & 8 & 0 & 0 & 1 & 1 & 10 & $\% 80$ \\
\hline Su kütleleri & 0 & 4 & 0 & 0 & 0 & 4 & $\% 100$ \\
\hline Tarım alanı & 0 & 0 & 13 & 0 & 0 & 13 & $\% 100$ \\
\hline Yeşil alan & 0 & 0 & 0 & 18 & 1 & 19 & $\% 94.74$ \\
\hline Boş alan & 1 & 1 & 0 & 0 & 52 & 54 & $\% 96.30$ \\
\hline $\begin{array}{c}\text { Üretici } \\
\text { doğruluğu }\end{array}$ & $\% 88.89$ & $\% 80$ & $\% 100$ & $\% 94.74$ & $\% 96.30$ & \multicolumn{2}{|c|}{$\begin{array}{c}\text { Genel sınıflandırma doğruluk } \\
\text { değeri \%95 }\end{array}$} \\
\hline Kappa değeri & 0.7802 & 1.0000 & 1.0000 & 0.9350 & 0.9195 & \multicolumn{2}{|c|}{$\begin{array}{c}\text { Ortalama kappa değeri } \\
0.9224\end{array}$} \\
\hline
\end{tabular}


Türk Tarım ve Doğa Bilimleri Dergisi 6(3): 536-545, 2019

Çizelge 3. 2000 yılı kontrollü sınıflandırma hata matrisi ve doğruluk analizi

\begin{tabular}{cccccccc}
\hline Sınıf adı & Yerleşim alanı & Su kütleleri & Tarım alanı & Yeşil alan & Boş alan & Satır toplamı & $\begin{array}{c}\text { Kullanıcı } \\
\text { doğruluğu }\end{array}$ \\
\hline $\begin{array}{c}\text { Yerleşim alanı } \\
\text { Su kütleleri }\end{array}$ & 15 & 0 & 0 & 1 & 1 & 17 & $\% 88.24$ \\
$\begin{array}{c}\text { Tarım alanı } \\
\text { Yeşil alan }\end{array}$ & 0 & 5 & 0 & 0 & 0 & 5 & $\% 100$ \\
Boş alan & 0 & 0 & 13 & 0 & 0 & 13 & $\% 100$ \\
\hline $\begin{array}{c}\text { Üretici } \\
\text { doğruluğu }\end{array}$ & $\% 100$ & 0 & 0 & 1 & 37 & 38 & $\begin{array}{c}\% 3.10 \\
\% 97.30\end{array}$ \\
\hline Kappa değeri & 0.8616 & 1.0000 & 1.0000 & 0.9497 & 0.9564 & $\begin{array}{c}\text { Ortalama kappa değeri } \\
\mathbf{0 . 9 4 5 5}\end{array}$ \\
\hline
\end{tabular}

Çizelge 4. 2017 yılı kontrollü sınıflandırma hata matrisi ve doğruluk analizi

\begin{tabular}{cccccccc}
\hline Sınıf adı & $\begin{array}{c}\text { Yerleşim } \\
\text { alanı }\end{array}$ & Su kütleleri & $\begin{array}{c}\text { Tarım } \\
\text { alanı }\end{array}$ & Yeşil alan & Boş alan & Satır toplamı & Kullanıcı doğruluğu \\
\hline Yerleşim alanı & 22 & 0 & 0 & 2 & 0 & 24 & $\% 91.67$ \\
Su kütleleri & 0 & 3 & 0 & 0 & 0 & 3 & $\% 100$ \\
Tarım alanı & 0 & 0 & 13 & 0 & 0 & 13 & $\% 100$ \\
Yeşil alan & 1 & 0 & 0 & 23 & 1 & 25 & $\% 9 . .00$ \\
Boş alan & 1 & 0 & 0 & 2 & 32 & 35 & $\% 88.57$ \\
\hline Üretici & $\% 91.67$ & $\% 100$ & $\% 100$ & $\% 82.14$ & $\% 96.88$ & $\begin{array}{c}\text { Genel sınıflandırma doğruluk } \\
\text { değeri \%92 }\end{array}$ \\
doğruluğu & & & & & & & \\
\hline Kappa değeri & 0.8904 & 1.0000 & 1.0000 & 0.8889 & 0.8319 & Ortalama kappa değeri 0.8923 \\
\hline
\end{tabular}

\section{5-2000-2017 yılı arazi örtüsü /alan kullanımı}

Bingöl kent merkezinin gelişimin daha doğru izlenebilmesi için AÖ/AK değişiminin analiz edilmesi amacıyla 1985 ve 2000 yilı Landsat TM uydu görüntüleri ve 2017 yılı Sentinel-2 uydu görüntülerinin kontrollü sınıflandırımasına ait tematik haritalar elde edilmiştir. Şekil 4'de 1985, 2000 ve 2017 yılına ait tematik haritalar belirtilmiştir. Sınıflandırma için belirlenen 5 ana sınıfın birbirinden ayırt edilebilmesi için yerleşim alanları kırmızı, yeşil alanlar yeşil, tarım alanları sarı, su kütleleri mavi ve boş alanlar açık kahverengi ile renklendirilmiştir.

1985 yılında, kentsel alanların kent merkezinin kuruluş alanı olanı Çapakçur vadisinin güney kısmında yoğunlaştığı kuzeyde ise daha az olarak yayılış gösterdiği görülmektedir. 2000 yılında ise Bingöl kent merkezinde kentsel alanlarının kuzey yönünde daha çok artış gösterdiği gözlemlenmiştir. Kentin kuzeyinde bulunan ormanlık alanların imara açılması ve Elazığ-Bingöl-Muş şehirlerarası karayolunun bu alan üzerinde konumlanmış olması yerleşim alanların bu yönde gelişim göstermesine neden olduğu sonucuna ulaşılmıştır. 2017 yılına gelindiğinde kent merkezindeki kentsel alanlarda kentin kuzey ve güney yönlü değişimin devam ettiği fakat kuzeyinde daha yoğun yaşandığı, Elazığ-Bingöl-
Muş şehirlerarası karayolu boyunca yerleşim alanlarının gelişim gösterdiği ve böylelikle kentin doğu bölgesinde genişlemenin olduğu analiz edilmiştir.

\section{5-2000 yılı arazi örtüsü/alan kullanımı değişimi} 1985-2000 yıllarına ait kontrollü sınıflandırılmış görüntülerin vektörize edilmesi elde edilen alansal verilerin ne kadar ve ne yönde değiştiği değerlendirilmiştir. 1985-2000 yılları arası arazi örtüsü/alan kullanım değişimi şekil 5'de grafiksel olarak gösterilmiştir.

1985-2000 yılları arasında yerleşim alanlarında $\% 75,13$, yeşil alan miktarında $\% 46,6$ oranında bir artış, su kütlelerinde $\% 31,03$, tarım alanlarında $\% 0.4$, boş alanlarda \%32,37 oranında bir azalma analiz edilmiştir. Yerleşim alanlarının ve yeşil alanların iki kata yakın artış göstermesi en dikkat çekici değişim olduğu gözlemlenmiştir. Köyden kente göç olaylarının yaşanması, nüfus artışına bağlı olarak yerleşim birimlerine ihtiyaç doğması, kamu kurumlarının yaygınlaşması, şehrin ortasından geçen Elazığ-BingölMuş karayolunun doğrultusunda kentsel gelişimin hızlı ilerlemesi vb. diğer sebepler yerleşim alanlarının artış göstermesi nedenleri olarak verilebilmektedir. 


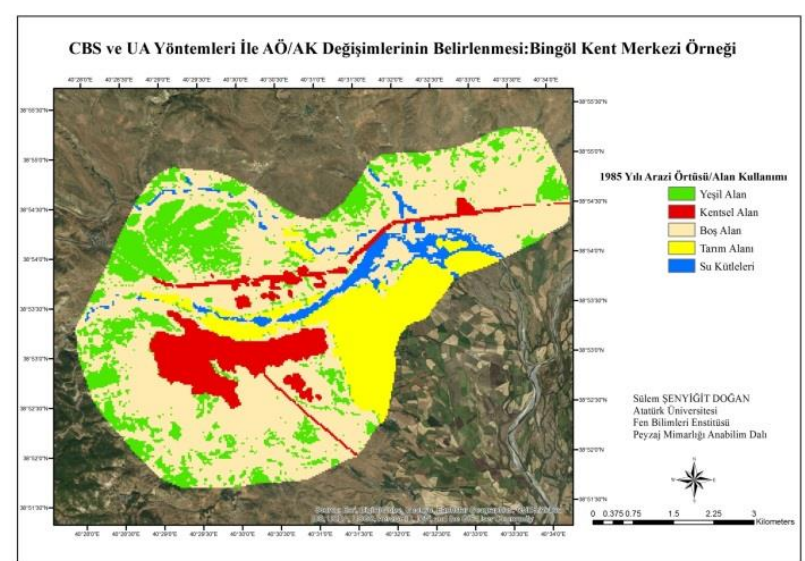

(a)

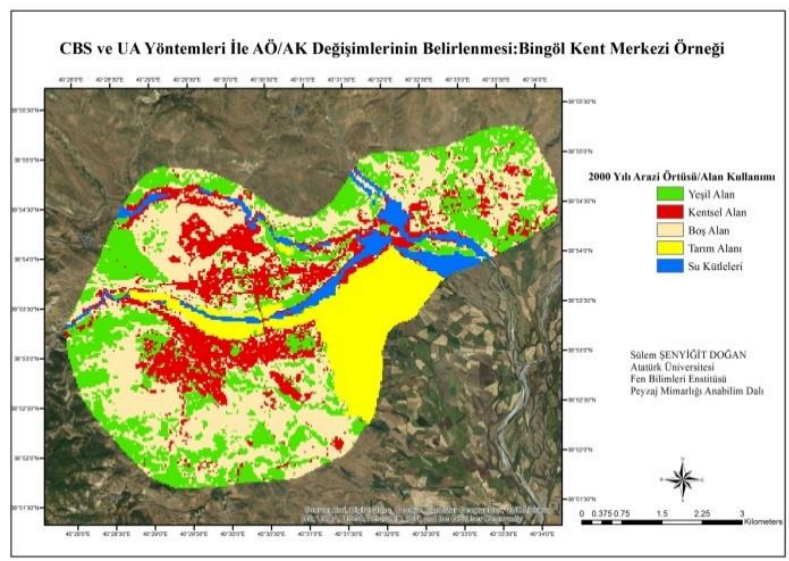

(b)

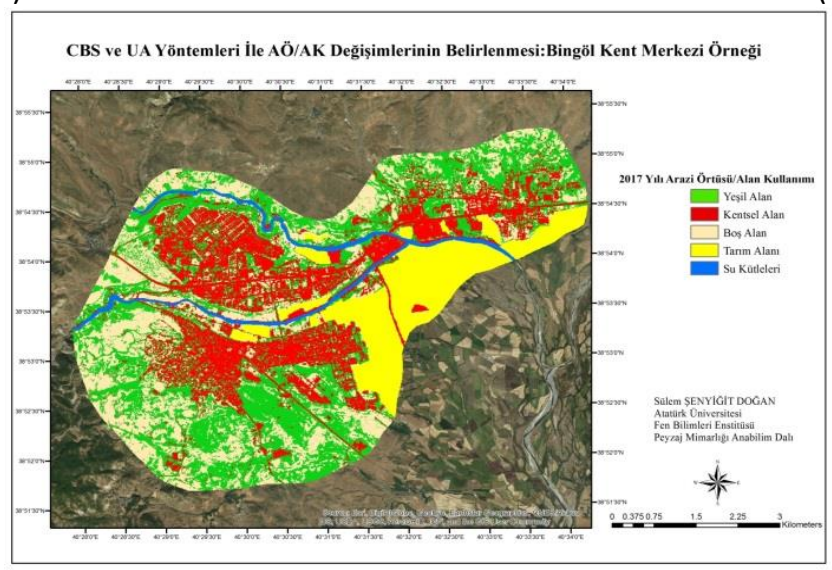

(c)

Şekil 4. Bingöl kent merkezi (a) 1985, (b) 2000 ve (c) 2017 yılları arazi örtüsü/alan kullanım haritaları.

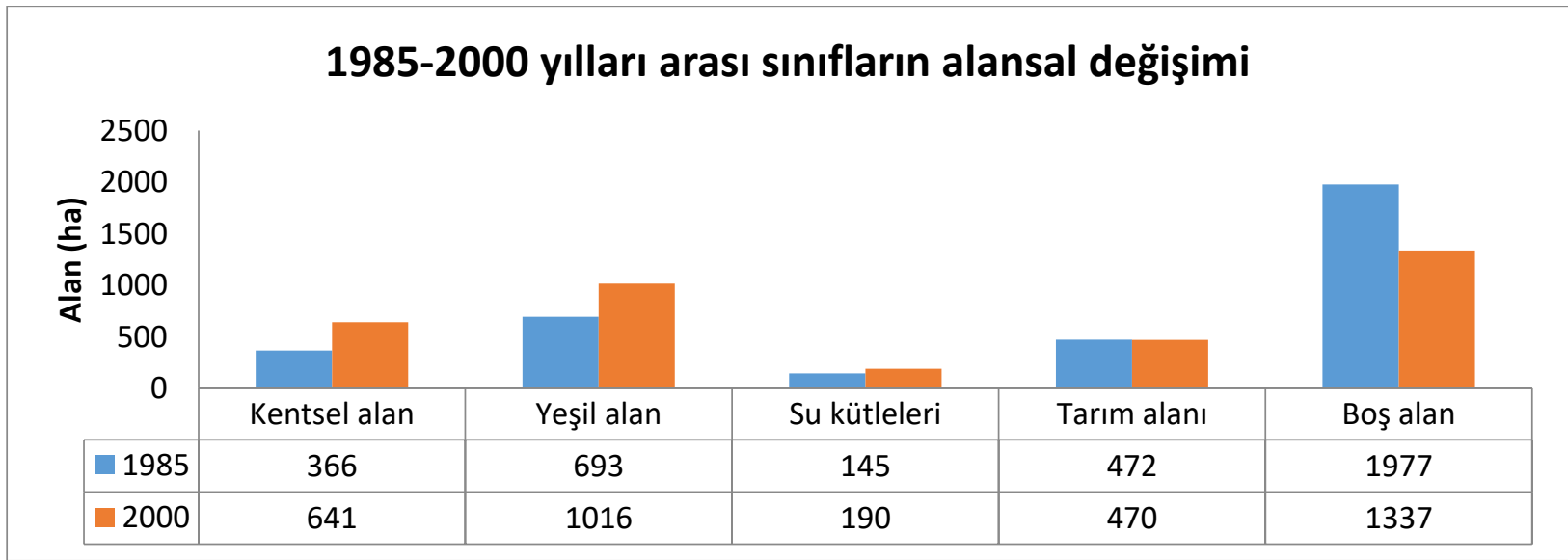

Şekil 5. 1985-2000 yılları arası sınıfların alansal değiş̧imi.

\section{0-2017 yılı arazi örtüsü/alan kullanımı değişimi}

Yaklaşık 17 yıllık değişimi gösteren Şekil 6'dan anlaşılacağı üzere yerleşim alanlarında önemli bir artış, yeşil alan, su kütleleri ve boş alanlarda azalış, tarım alanlarında ise çok az miktarda bir azalış olduğu gözlemlenmektedir.
2000-2017 yılları arasında yerleşim alanlarında Şekil 6\%36,9, tarım alanlarında \%3,19 oranında bir artış, yeşil alanlarda $\% 9,05$, su kütlelerinde $\% 52,21$ ve boş alanlarda \%5,38 oranında bir azalma olduğu analiz edilmiştir. Kent yaşamına olan talep gibi sebeplerin yanında 1 Mayıs 2003 yılında yaşanan 
deprem felaketi sonucunda kırsalda bulunan konutların tahrip olmasıyla kent merkezinde genelde iki katlı olan deprem konutlarının inşa edilmesi ve köy halkının merkezlerdeki bu konutlara yerleştirilmesi ve eğitim ve sağlık gibi kamusal alanların artması ve bu durumlara bağlı olarak kentsel nüfus oranının artış göstermesi Bingöl kent merkezi yerleşim alanlarının hızlı artışına neden olmuştur.

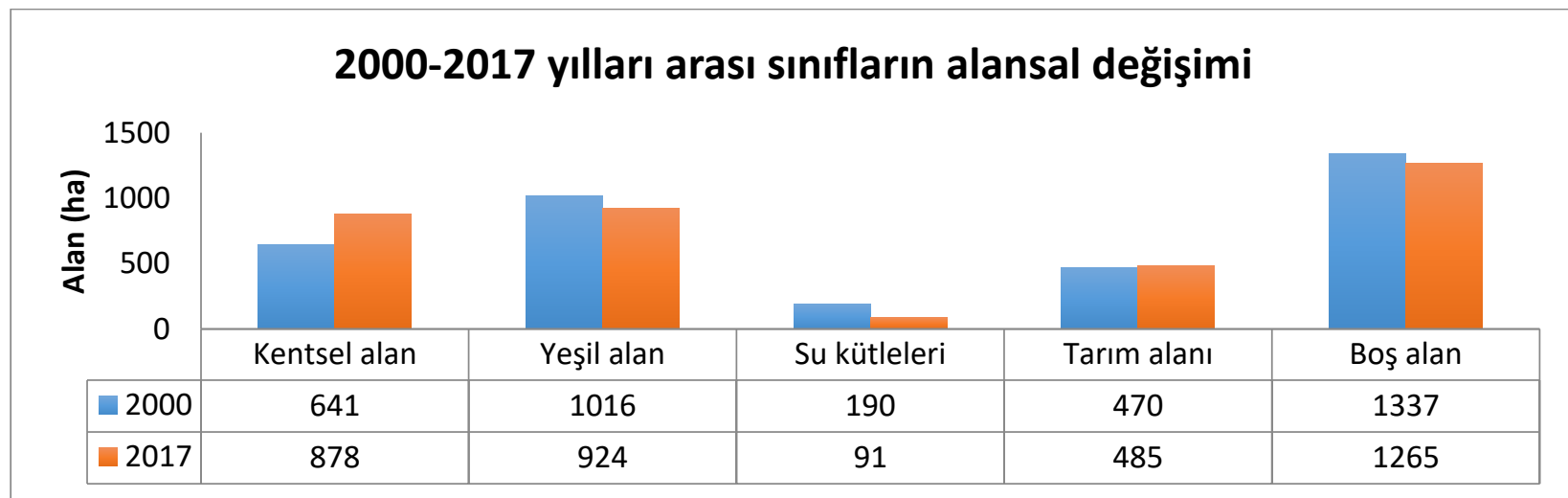

Şekil 6. 2000-2017 yılları arası sınıfların alansal değişiminin grafiksel gösterimi.

Bir diğer en büyük değişim sebebi ise 2007 yılında Bingöl Üniversitesinin kent merkezindeki ana binasıyla eğitim-öğretim faaliyetlerine başlamış olmasıdır. O tarihten itibaren kampüs alanındaki eğitim binası sayısını arttırmakla birlikte aynı zamanda kent merkezine önemli derecede bir hareketlilik getirdiği gözlemlenmektedir. Kent merkezine eğitim-öğretim getirmekle kalmayıp aynı zamanda oluşturduğu kaynakla istihdam ortamı oluşturmuş ve çektiği öğrenci sayısı ile de nüfus artışı yaşanmıştır. Artan nüfus ile birlikte yeni yerleşim ihtiyacı doğmuştur.

\section{5-2000-2017 yılı arazi örtüsü/alan kullanımı değişimi}

Çalışmanın temel amacı olan 1985 yılından 2017 yılına kadar çalışma alanında meydana gelen
AÖ/AK değişimi grafiksel olarak gösterilmiştir (Şekil 7).

32 yıllık süreçte en büyük artışı gerçekleşen sınıf olan yerleşim alanlarında yaklaşık olarak 512 ha'lık artış, yeşil alanlarda 231 ha artış, su varlığında 54 ha azalış, tarım alanlarında 13 ha'lık bir artış ve boş alanlarda 712 ha'lık bir azalış olduğu analiz edilmiştir. Yerleşim alanları yaklaşık olarak \%139,89, yeşil alanlarda \%33,33 ve tarım alanlarında \%2,75 oranında bir artış, boş alanlarda \%36,01 ve su kütlelerinde \%37,24 oranında bir azalma olduğu görülmektedir. Yerleşim alanlarındaki artış oranı çalışmanın odak noktasını oluşturmaktadır. Hızlı yapılaşmanın son dönemlerde hızla gerçekleştiği kent merkezindeki bu artış olası bir sonuç olarak görülmektedir.

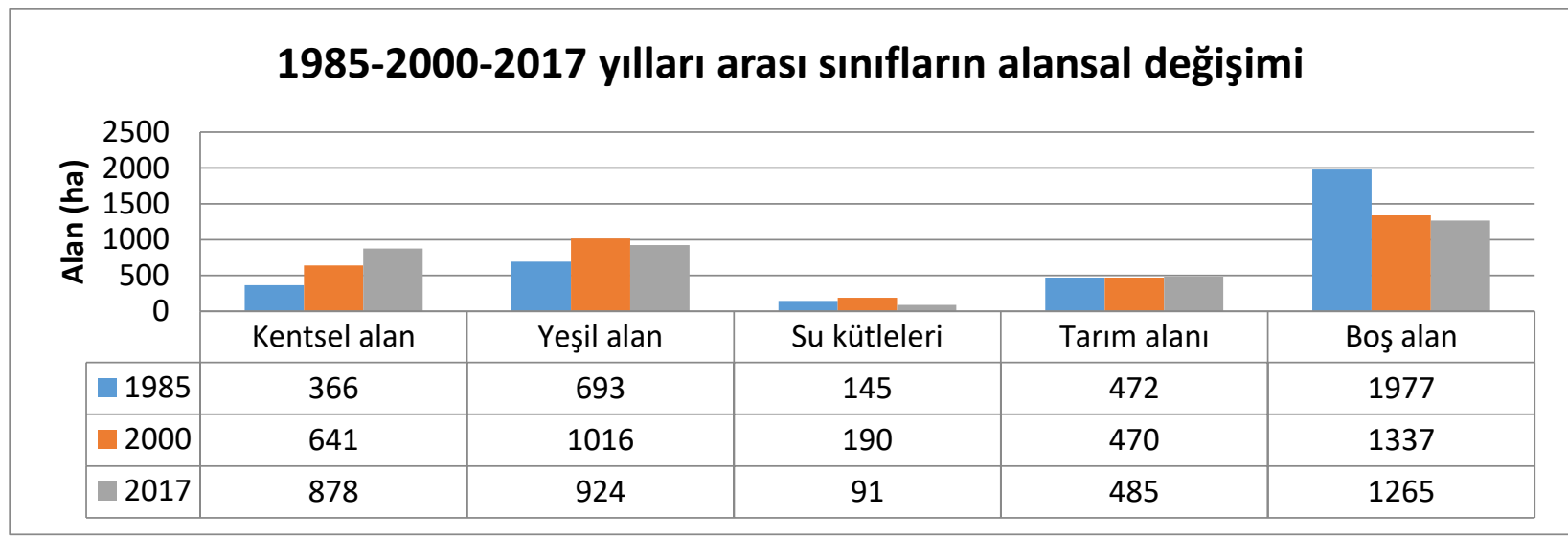

Şekil 7. 1985-2000-2017 yılları arası sınıfların alansal değişimin grafiksel gösterimi. 


\section{Sonuç ve Öneriler}

Türkiye'nin genelinde yaşanan hızlı kentleşme Bingöl kent merkezinde de gözlemlenmiştir. Yapılan uygulamalar sonucu, 1985-2017 yılları arasında Bingöl kent merkezinde hızlı bir kentleşme meydana geldiği analiz edilmiştir. 1985 yılında kentsel alanlar yaklaşık 366 ha'lık bir alanı kapsarken 2017 yılına gelindiğinde ise 512 ha'lık bir alan artışı sergilemiş ve yaklaşık olarak iki katından da fazla olan 878 ha'a ulaşmıştır. Yerleşim alanları 1985 yılında çalışma alanı olan kent merkezinin \%10.01'lik bir bölümünü oluşturmaktayken, 32 yıl sonrası olan 2017 yılında ise \%34,62'lik bir bölümünü oluşturmaktadır. Elde edilen bu sonuç, aynı yöntemle AÖ/AK değişimini analiz ettikleri çalışmalarında Calda, (2010)'nun Kayseri kentinde 1987 yılında yerleşim alanlarının 34,1 $\mathrm{km}^{2}$ den 2009 yılında 136,4 km²'ye kadar artış gösterdiği ve Gezici, (2012)'nin Konya kentinde yerleşim alanlarının 1985 yılında 43,22 km²'den 2011 yılına kadar üç kat kadar artış göstererek 146,51 $\mathrm{km}^{2}$ ye ulaştığı sonucu ile paralellik göstermektedir.

Dünya genelinde çeşitli nedenlerle kent merkezlerinde yaşanan nüfus artışı Türkiye genelinde de gözlemlenmektedir. Bingöl kent merkezi nüfus oranı olarak TÜik verilerine göre 32 yıllık süreçte nüfus sayısı 34024'den, 117011'e kadar yükselme göstermektedir ve oluşan bu durum yerleşim alanının genişlemesine ve arazi örtüsü değişimine neden olmuştur. Bu sonuç Yücer ve Erener (2016)'nın Erzincan kenti için kentsel alan değişimini analiz ettikleri çalışmalarında 1987 yılından 2000 yılına kadar nüfusun 24,559 arttığı ve buna bağlı olarak şehir alanında mekânsal büyümenin gerçekleştiği ve alan kullanımlarında değişime sebebiyet verdiği sonucu ile örtüşmektedir.

Kentsel alanlardaki bu artışın önemli ölçüdeki kısmı Bingöl kent merkezinde boş alanlar üzerinde gerçekleşmiştir. Boş alan sınıfında bulunan alan kullanımları 1985 yılında 1977 ha alan kaplarken 2017 yılında 1267 ha alan kaplayarak yaklaşık 710 ha'lık bir alan, oransal olarak ise \%36 oranında azalış gösterdiği sonucuna ulaşılmıştır. Tarım alanları 1985 yılında 472 ha alan kaplarken 2017 yılına gelindiğinde ise 485 ha alan kapladığı ve \%3 oranında bir artış gösterdiği analiz edilmiştir. Kentin özellikle 2000'li yıllardan sonra Elazığ-Bingöl-Muş şehirlerarası karayolu doğrultusunda doğu yönünde yerleşim alanlarının artış göstermesi ile birlikte ana geçim kaynağı olan tarımsal faaliyetleri uygulamak için bu bölgede kullanılamayan arazileri tarım arazine dönüştürmesi ile bu değişim gerçekleşmiş boş alanlarda azalma yaşanmıştır. El-Kawy ve ark. (1984)'nın Mısır'ın kuzey bölgesini UA yöntemleri ile alansal değişimini analiz ettikleri çalışmalarında 1984 yılında 234 ha olan kullanılmayan arazilerinin yerleşim alanlarının artmasına bağlı tarım arazisine dönüştürülmesi ile 2009 yılında 73 ha kadar azaldığı sonucu ile paralellik göstermektedir. Yerleşim alanlarındaki bu değişimin önemli ölçüdeki kısmı Bingöl kent merkezinde boş alanlar üzerinde gerçekleşmiştir. Boş alan sınıfında bulunan alan kullanımları 1985 yılında 1977 ha alan kaplarken 2017 yılında 1267 ha alan kaplayarak yaklaşık 710 ha'lık bir alan, oransal olarak ise \%36 oranında azalış gösterdiği sonucuna ulaşılmıştır. Bu sonuç Doygun ve Erdem (2013)'ün İzmir'in Bornova ilçesi için uyguladıkları 25 yılı kapsayan çalışmalarında kentsel alanların 4440 ha büyüdüğünü ve bunun neticesinde çıplak alanların azaldığı, Calda (2010)'nun tez çalışmasında Kayseri kenti için yerleşim alanlarının artması ile kullanılmayan arazilerin 1987 yılında 869 km2'den 2009 yılında 451,2 km²'ye kadar azalış gösterdiği bulguları ile paralellik göstermektedir.

Yerleşim alanlarının artışına bağlı olarak boş alanlar ve seyrek bitki örtüsüne sahip alanlar üzerinde gerçekleşen bu artış Alphan ve ark., (2009)' un Kahramanmaraş kenti için yaptığı çalışmada 1984 ve 2004 yılları arasını kapsayan çalışmasında kentsel alanların 1,443.45 ha artışla ikiye katlandığı ve buna bağlı olarak tarım alanlarının da 1.075.79 ha alan seyrek bitki örtüsü alanlarından tarım alanlarına dönüştüğü bulgularıyla benzerlik göstermektedir. 1985-2017 yılları arası olan 32 yıllık süreci kapsayan çalışmada Bingöl kent merkezinde 231 ha'lık ve \%33,33 oranında bir artış yaşadığı sonucuna ulaşılmıştır. Bu artışın ana nedeni kent merkezi çevresinde doğal yayılış gösteren meşe (Quercus ssp.) türlerinin oluşturduğu orman alanlarının boş alanlar üzerine genişlemesidir. Yeşil alan varlığındaki bu değişim kent merkezinin gelişim yönünde de etkili olmuştur. Türkiye genelinde kent merkezleri batı yönlü bir genişleme sergilemekte iken Bingöl kent merkezi özellikle son dönemlerde doğu yönünde bir ilerleme göstermektedir. Kent merkezinin batısının yükseltilerle sınırlı olması, güney ve doğu bölgelerinde orman varlığının bulunması bunun nedeni olarak görülmektedir.

Sonuç olarak Bingöl kent merkezi AÖ/AK 'nın tespiti ve izlenmesi ile kentsel gelişimin hangi alan sınıfına daha çok baskı uygulandığı analiz edilmiştir. $\mathrm{Bu}$ baskılar daha çok yeşil alan ve boş alan üzerinde gerçekleşmiş, yanlış alan kullanımlarının da oluşması ile su varlığında azalma yaşanmıştır. Gelişen ve değişen kentsel ihtiyaçların karşılanabileceği aynı zamanda bütüncül arazi yönetimini de içeren planların yerel yönetimler tarafından kentsel 
palanlara entegre edilmesi ile sürdürülebilir AÖ/AK sağlanabilir, gelecek nesillere daha sağlıklı yaşam alanları kazandırılabilir.

¥: Bu makale Sülem ŞENYiĞiT DOĞAN'ın yüksek lisans tezinden üretilmiştir.

\section{Kaynaklar}

Alphan, H., Doygun, H., Ünlükaplan, Y. 2009. Postclassification comparison of land cover using multitemporal Landsat and ASTER imagery: the case of Kahramanmaraş, Turkey. Environ. Monit. Assess., 151(1-4): 327-336.

Anonim, 2018. https://glovis.usgs.gov/app (Erişim tarihi: 29.09.2018).

Calda, D. 2010. Uzaktan Algılama ve Coğrafi Bilgi Sistemi Yöntemleriyle Arazi Örtüsü/Kullanımı Değişiminin Analizi: Kayseri ilii Örneği. Yüksek Lisans Tezi, Havacılık ve Uzay Teknolojileri Enstitüsü, İstanbul.

Çelebi Zengin, E. 2018. Kent ve Kentlileşme Sarmalında Türkiye. Kastamonu Üniversitesi İktisadi ve İdari Bilimler Fakültesi Dergisi, 20(1): 85-103.

Doygun, H., Atmaca, M., Zengin, M. 2015. Kahramanmaraş'ta Kentleşme ve Yeşil Alan Varlığındaki Zamansal Değişimlerin İncelenmesi. KSÜ Doğa Bilimleri Dergisi, 18(4): 55-60.

Doygun, N., Erdem, Ü. 2013. Kentsel gelişim sürecinin alan kullanım yapısı üzerine etkilerinin incelenmesi: Bornova, İzmir örneği. Türk Bilimsel Derlemeler Dergisi, 6(1): 17-22.

El-Kawy, O.R., Abd, Rod, J.K., Ismail, H.A., Suliman, A.S. 2011. Land use and land cover change detection in the Western Nile Delta of Egypt using remote sensing data. Applied Geography, 31: 483-494.

Erdoğan, M.A. 2018. CBS'de Veri/Kaynak Analizi Dersi. Çukurova Üniversitesi Teknik Bilimler Meslek Yüksek Okulu, Adana.

Erkan, B., Şentürk, M., Akbaş, Y.E. 2012. Bingöl ilinin Türkiye'nin ihracat ve GSYH'sına Katkısının alt sektörler itibarıla incelenmesi. İstanbul Ticaret Üniversitesi Sosyal Bilimler Dergisi, 21: 107-126.

Gezici, A. 2012. Uzaktan Algılama ve CBS Entegrasyonu ile Arazi Örtüsü/Kullanımı Değişiminin Analizi; Konya ili Örneği. Yüksek Lisans Tezi, Havacılık ve Uzay Teknolojileri Enstitüsü, Konya.

Gülersoy, A.E. 2014. Seferihisar'da Arazi kullanımının zamansal değişimi (1984-2010) ve ideal arazi kullanımı için öneriler. SDÜ Fen Edebiyat Fakültesi Sosyal Bilimler Dergisi, 31: 155-180.

Oğuz, M., Zengin M. 2012. Peyzaj patern metrikleri ve Landsat 5 TM uydu görüntüleri kullanılarak arazi örtüsü/arazi kullanımı değişimi analizi (1984-2010): Kahramanmaraş örneği. KSÜ Mühendislik Bilimleri Dergisi, Özel Sayı: 22-29.

Özturk, M., Mermut, A., Çelik, A. 2010. Land Degradation, Urbanisation, Land Use Environment. NAM Science \& Technology Centre, $445 \mathrm{p}$.

Ramachandra, T.V., Bharath, H.A. 2012. Land use dynamics at Padubidri, Udupi district with the implementation of large scale thermal power project. International Journal of Earth Sciences and Engineering, 5(3): 409-417.

Rawat, J.S., Kumar, M. 2015. Monitoring land use/cover change using remote sensing and GIS techniques: A case study of Hawalbagh block, district Almora, Uttarakhand, India. The Egyptian Journal of Remote Sensing and Space Science, 18(1): 77-84.

Seymen, i.., Aydın, A. 1972. Bingöl deprem fayı ve bunun Kuzey Anadolu fay zonu ile ilişkisi. http://dergipark.gov.tr/download/articlefile/111059 (11.10.2018).

Şahap, A. 2015. Uzaktan Algılama ve Coğrafi Bilgi Sistemleri Kullanarak Şehirsel Gelişimin Arazi Kullanımına Etkisi: Şanlıurfa Şehri Örneği. Yüksek Lisans Tezi, Fen Bilimleri Enstitüsü, Şanlıurfa.

Tonbul, S. 1990. Bingöl Ovası ve çevresinin jeomorfolojisi ve gelişimi. Coğrafya Araştırmaları Dergisi, 2(2): 329-352.

TÜiK, 2017. Adrese Dayalı Nüfus Kayıt Sistemi Sonuçları. Kaynak: file:///C:/Users/LZ/Downloads/Adrese_Dayal \%C4\%B1_N\%C3\%BCfus_Kay\%C4\%B1t_Sis t_31.01.2017.pdf, (Erişim tarihi: 05.12.2018).

Vural, H. 2019. Bingöl Ilıcalar beldesi ve yakın çevresinin peyzaj özellikleri ve kırsal turizm potansiyeli. Bingöl Üniversitesi Sosyal Bilimler Enstitüsü Dergisi, 9(17): 381-410.

Yücer, E., Erener, A. 2016. Kentsel Alan Değişiminin Uydu Görüntüleri ille Zamansal Takibi. Uluslararası Erzincan Sempozyumu, Erzincan. 